Article

\title{
Light Grazing Significantly Reduces Soil Water Storage in Alpine Grasslands on the Qinghai-Tibet Plateau
}

\author{
Xiaowei Guo ${ }^{1,2}$, Licong Dai ${ }^{1,3}$, Qian Li $^{1,2}$, Dawen Qian ${ }^{1,2}{ }^{10}$, Guangmin Cao ${ }^{1,2}$, \\ Huakun Zhou ${ }^{1,2}$ and Yangong Du ${ }^{1,2, *}$ \\ 1 Key Laboratory of Adaptation and Evolution of Plateau Biota, Northwest Institute of Plateau Biology, \\ Chinese Academy of Sciences, Xining 810008, China; guoxw@nwipb.cas.cn (X.G.); \\ g12004242553@163.com (L.D.); 18697190176@163.com (Q.L.); dwqian@nwipb.cas.cn (D.Q.); \\ caogm@nwipb.cas.cn (G.C.); hkzhou@nwipb.cas.cn (H.Z.) \\ 2 Qinghai Provincial Key Laboratory of Restoration Ecology for Cold Regions, Xining 810008, China \\ 3 College of Resource and Environment, University of the Chinese Academy of Sciences, Beijing 100000, China \\ * Correspondence: ygdu@nwipb.cas.cn
}

Received: 12 February 2020; Accepted: 21 March 2020; Published: 23 March 2020

\begin{abstract}
The degradation of alpine grasslands directly affects their ability to conserve water, but changes in soil water storage in grassland under different degrees of degradation are poorly understood. Here, we selected four grassland plots along a degradation gradient: no-degradation grassland (NG), lightly degraded grassland (LG), moderately degraded grassland (MG) and severely degraded grassland (SG). We then applied an automatic soil moisture monitoring system to study changes in soil water storage processes. Results revealed significant $(p<0.05)$ differences in soil water storage among NG, LG, MG and SG. Specifically, LG lost $35.9 \mathrm{~mm}$ of soil water storage compared with NG, while soil water storage in LG, MG and SG decreased by $24.5 \%, 32.1 \%$ and $36.7 \%$, respectively. The shallow groundwater table, air temperature and grass litter were the key controlling factors of soil water storage in the grassland. Grazing and future global warming will significantly reduce soil water storage in alpine grasslands.
\end{abstract}

Keywords: alpine grasslands; degraded grassland; grass litter; soil water storage

\section{Introduction}

With rapid growth of the global population, the freshwater crisis has become a global strategic problem second only to the shortage of oil resources. The Qinghai-Tibet Plateau, as the source of many of China's and South East Asia's rivers, is rich in water resources and is called China's water tower. As such, the region plays an important role in ensuring water security [1]. Alpine grassland is an important basis for water conservation on the Qinghai-Tibet Plateau. Alpine grassland is the most representative vegetation type on the Plateau. Its degradation has a profound impact not only on China but also global ecological security [2,3], thereby generating global interest.

Soil water is an important element in ecological systems, connecting soil, vegetation and atmosphere. Climate change and human activities are the two major driving factors affecting the quantity and cycling of soil water. Soil moisture has received considerable research attention, revealing that changes in soil water can be controlled by temperature, precipitation, vegetation, freeze-thaw, soil texture and other factors [4]. Of these, temperature is the main driving force of soil water migration, while precipitation is the main source of soil water. Plants affect soil moisture through precipitation interception and transpiration [5]. Soil texture affects the water holding capacity and water retention, thereby affecting the movement of water in the soil [6]. 
Heavy grazing can lead to serious grassland degradation within three to five years, yet grassland degradation is considered one of the main reasons for the decrease in the water-conservation function across the Qinghai-Tibet Plateau [7]. Some progress has been made by research that has addressed the effect of grassland degradation on the water-conservation function of the Qinghai-Tibet Plateau. The decrease in soil organic matter after grassland degradation reduces soil water retention capacity [8]. Changes in soil particle size and aggregate structure also contribute to soil desiccation. Even in the extremely degraded grasslands that have been reclaimed for conversion into artificial grasslands, there is no significant improvement in water-retention capacity [9]. With an increase in grazing intensity, the soil saturated moisture capacity, the capillary moisture capacity, and the field moisture capacity do not increase linearly; they all increase initially but then decrease, with a peak at the stage of moderate degradation. Compared to native grasslands, the saturated and field moisture capacity in moderately degraded grasslands increased by $17.1 \%$ and $5.8 \%$, respectively [10]. However, when the grassland became severely degraded or extremely degraded, the saturated moisture capacity, capillary moisture capacity, and field moisture capacity of the grassland decreased sharply [11]. Grassland degradation has reduced the water-conservation function in the Qinghai-Tibet Plateau by $18.3 \%-27.8 \%$ [12]. Therefore, avoiding the severe degradation of alpine grasslands is key to ensuring the maintenance of its ecological functions.

Previous studies mainly focused on comparing water conservation of degraded and non-degraded grassland; however, in reality most degraded grasslands are in a state of light or moderate degradation. Therefore, it is necessary to study the water storage of grasslands under different degrees of degradation to improve our understanding of the water-conservation function of alpine grassland on the Qinghai-Tibet Plateau. Grassland degradation causes a series of function degradation in grassland, such as the loss of plant species, soil desertification, the decreasing of above-ground biomass and vegetation coverage and the structural failure of soil aggregates. These grassland environmental factors had an important effect on soil moisture content, so we propose the hypothesis that lightly and moderately degraded grasslands will lose a large proportion of their soil water storage.

\section{Materials and Methods}

\subsection{Site Description and Experimental Design}

The study was carried out during June 2017 to October 2018 at the Haibei National Field Research Station in the alpine grassland ecosystem $\left(101^{\circ} 19^{\prime} \mathrm{E}, 37^{\circ} 37^{\prime} \mathrm{N}, 3200 \mathrm{~m}\right.$ above sea level), which is in the northeastern region of the Qinghai-Tibet Plateau. The region has well-developed, seasonally frozen ground and is characterized by a plateau continental monsoon climate. The annual average air temperature is $-1.70{ }^{\circ} \mathrm{C}$ and the annual precipitation is $570 \mathrm{~mm}$. The vegetation type is that of a typical alpine meadow, where the dominant species in the alpine Kobresia meadow include Kobresia humilis (C. A. Mey.) Serg., Elymus nutans Griseb, Stipa aliena Keng, Taraxacum dissectum (Ledeb) Ledeb, Anaphalis lactea Maxim and Potentilla anserina L. Sp. Pl. The soil at this site is classified as Calcic Cryosols [13], which has a high content of organic matter $(7 \%, 0-10 \mathrm{~cm})$.

We selected four homogeneous winter alpine meadow sites along the grazing intensity gradient. The four experimental sites were established in 2015 and each site was fenced with barbed wire and had the area of $400 \times 400 \mathrm{~m}$. We paid a certain fee to herdsmen so they could determine the grazing intensity. The criteria for site selection were based on a clear decline in the coverage of palatable grasses (all sedges and graminoids and some legumes and little forbs) [14]. Following other studies [15], we defined absolute abundances of palatable grasses of $<20,20-70,70-90$ and $>90 \%$ as corresponding to degradation levels severely degraded grassland (SG), moderately degraded grassland (MG), lightly degraded grassland (LG) and no-degradation grassland (NG), respectively. Therefore, grazing management could be considered to be the primary factor influencing variations in degradation status. The vegetation coverage of SG was higher than that in MG because heavy grazing 
resulted in a lot of patchy bare land where only a few poisonous weeds had grown, thus the vegetation coverage of SG was higher than MG. Detailed information about the four sites is provided in Table 1.

Table 1. Characteristics in the four plots during the studied period.

\begin{tabular}{|c|c|c|c|c|}
\hline $\begin{array}{l}\text { Degradation } \\
\text { Classification * }\end{array}$ & $\begin{array}{l}\text { No-Degradation } \\
\text { Grassland (NG) }\end{array}$ & $\begin{array}{l}\text { Lightly Degraded } \\
\text { Grassland (LG) }\end{array}$ & $\begin{array}{c}\text { Moderately } \\
\text { Degraded } \\
\text { Grassland (MG) }\end{array}$ & $\begin{array}{c}\text { Severely } \\
\text { Degraded } \\
\text { Grassland (SG) }\end{array}$ \\
\hline Location & $101^{\circ} 18.798^{\prime} \mathrm{E}$ & $101^{\circ} 2.698^{\prime} \mathrm{E}$ & $101^{\circ} 10.620^{\prime} \mathrm{E}$ & $101^{\circ} 18.237^{\prime} \mathrm{E}$ \\
\hline Grazing management *** & $\begin{array}{c}37^{\circ} 36.666^{\prime} \mathrm{N} \\
3.5 \text { sheep } / \mathrm{hm}^{2}\end{array}$ & $\begin{array}{c}37^{\circ} 52.189^{\prime} \mathrm{N} \\
8.5 \mathrm{sheep} / \mathrm{hm}^{2}\end{array}$ & $\begin{array}{c}37^{\circ} 40.054^{\prime} \mathrm{N} \\
11.5 \text { sheep } / \mathrm{hm}^{2}\end{array}$ & $\begin{array}{l}37^{\circ} 36.676^{\prime} \mathrm{N} \\
20 \text { sheep } / \mathrm{hm}^{2}\end{array}$ \\
\hline Exposed soil coverage (\%) & $1 \pm 1.0 \mathrm{a}$ & $8.4 \pm 2.6$ & $34.0 \pm 2.5$ & $21.8 \pm 5.9$ \\
\hline $\begin{array}{c}\text { Palatable species absolute } \\
\text { coverage }(\%)\end{array}$ & $183.6 \pm 42.48$ & $42.4 \pm 4.88$ & $41.6 \pm 7.24$ & $4.4 \pm 2.2$ \\
\hline $\begin{array}{c}\text { Inedible species absolute } \\
\text { coverage }(\%)\end{array}$ & $132.0 \pm 24.66$ & $56.4 \pm 10.84$ & $63.3 \pm 8.19$ & $95.7 \pm 2.19$ \\
\hline $\begin{array}{c}\text { Inedible species } \\
\text { aboveground biomass } \\
\left(\mathrm{g} / \mathrm{m}^{2}\right)\end{array}$ & $126.8 \pm 33.28$ & $23.2 \pm 0.6$ & $101.2 \pm 18.04$ & $182.8 \pm 41.24$ \\
\hline Soil compactness ${ }^{* *}(\mathrm{Kg})$ & $24.1 \pm 3.2$ & $27.6 \pm 2.2$ & $28.1 \pm 2.5$ & $27.1 \pm 3.7$ \\
\hline $\begin{array}{c}\text { Soil organic matter ** } \\
(\mathrm{g} / \mathrm{kg})\end{array}$ & $244.6 \pm 24.7$ & $273.8 \pm 33.1$ & $244.6 \pm 22.9$ & $180.87707 \pm 27.2$ \\
\hline Root biomass ** $\left(\mathrm{g} / \mathrm{m}^{3}\right)$ & $4570.3 \pm 129.3$ & $4329.2 \pm 339.6$ & $4118.1 \pm 496.7$ & $4007.9 \pm 773.2$ \\
\hline Soil total nitrogen ${ }^{* *}(\mathrm{~g} / \mathrm{kg})$ & $11.9 \pm 1.2$ & $11.8 \pm 1.9$ & $10.1 \pm 3.6$ & $8.1 \pm 3.5$ \\
\hline Soil bulk density ** $\left(\mathrm{g} / \mathrm{cm}^{3}\right)$ & $0.68 \pm 0.13$ & $0.72 \pm 0.09$ & $0.78 \pm 0.13$ & $0.72 \pm 0.16$ \\
\hline $\begin{array}{c}\text { Dominant species } \\
\text { composition and plant } \\
\text { community description }\end{array}$ & $\begin{array}{l}\text { Two-layer canopy } \\
\text { Upper canopy: Stipa } \\
\text { aliena, Helictotrichon } \\
\text { tibeticum, Elymus nutans; } \\
\text { Lower canopy: Kobresia } \\
\text { humilis, Scirpus } \\
\text { distigmaticus, Poa } \\
\text { crymophila, } \\
\text { Dracocephalum } \\
\text { heterophyllum Benth }\end{array}$ & $\begin{array}{l}\text { One-layer canopy } \\
\text { Stipa aliena, Poa } \\
\text { crymophila, Kobresia } \\
\text { humilis, } \\
\text { toxic species: } \\
\text { Oxytropis } \\
\text { kansuensis, } \\
\text { Leontopodium } \\
\text { hastioides, Morina } \\
\text { chinensis }\end{array}$ & $\begin{array}{l}\text { Shorter vegetation } \\
\text { canopy: Kobresia } \\
\text { pygmaea, Saussurea } \\
\text { superba, Gentiana } \\
\text { straminea, Oxytropis } \\
\text { kansuensis, } \\
\text { Leontopodium } \\
\text { hastioides }\end{array}$ & $\begin{array}{c}\text { Elsholtzia } \\
\text { calycocarpa, Ajania } \\
\text { tenuifolia, } \\
\text { Polygonum } \\
\text { sibiricum, } \\
\text { Ligularia } \\
\text { virgaurea, } \\
\text { Potentilla anserina }\end{array}$ \\
\hline
\end{tabular}

${ }^{*}$ Data presented as means \pm 1SE of three replicates. ${ }^{* *}$ The data of soil compactness, soil organic matter, soil total nitrogen and oil bulk density in the table were the value at the $0-10 \mathrm{~cm}$ depth, and the root biomass was the total value at the $0-40 \mathrm{~cm}$ depth. **** The grazing intensity of SG was 20 sheep $/ \mathrm{hm}^{2}$ before 2015 . Now SG cannot withstand excessive grazing intensity, whose grazing intensity is $0.5 \mathrm{sheep} / \mathrm{hm}^{2}$. Italics are the Latin names of plants.

\subsection{Data Collection}

Daily meteorological data were obtained from a meteorological station (Molis 520; Vaisala, Finland) between 2017 and 2018 (Figure 1). The meteorological parameters included relative humidity, wind speed, net radiation, soil temperature and mean air temperature. Precipitation was collected using a precipitation gauge (52,203, RM Young, USA) at a height of $0.5 \mathrm{~m}$. An automatic soil moisture monitoring system (CR800; Campbell, USA) was installed at depths of 5, 20 and $40 \mathrm{~cm}$ below the ground surface (Figure 1). The plant community was surveyed every month in the growing season using a grid method of quadrat survey procedure $(0.5 \times 0.5 \mathrm{~m})$. Absolute coverage was calculated based on the occurrence within the 100 points, and the above-ground biomass (AGB) for each species was obtained by a standard harvesting method. Species diversity was measured based on the relative AGB of each plant species in the same quadrat. 


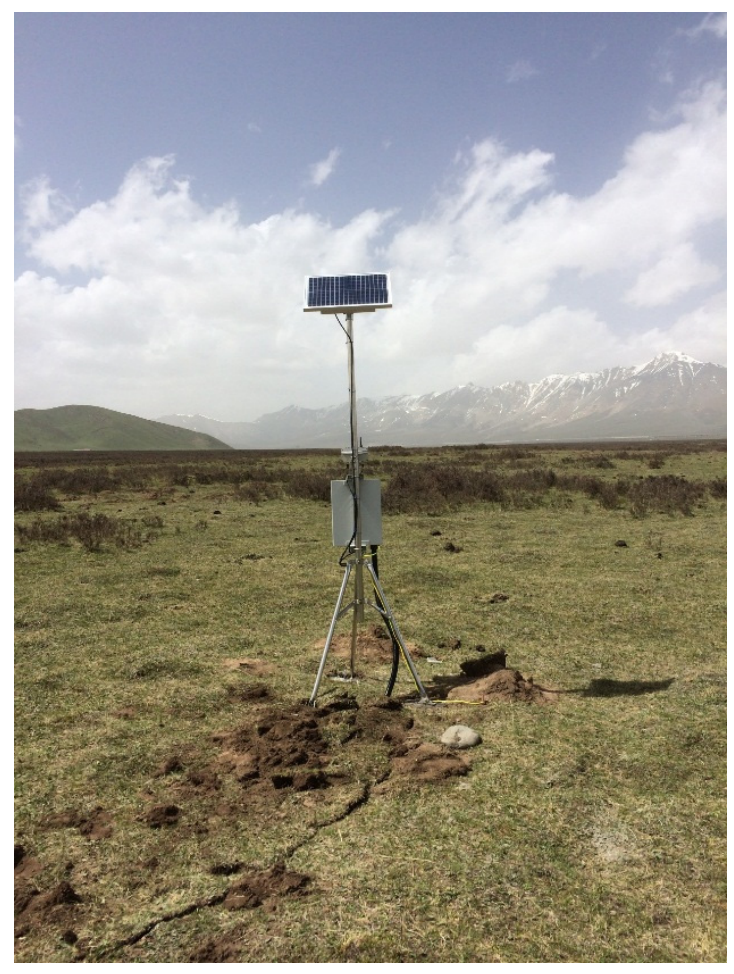

(a)

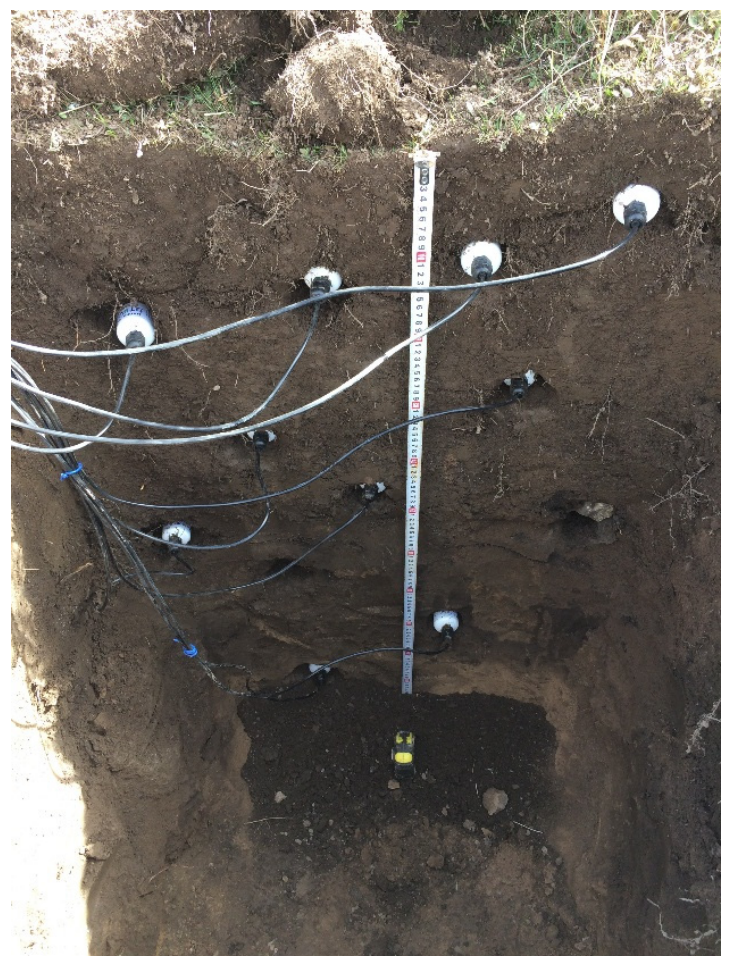

(b)

Figure 1. The automatic soil moisture monitoring system. (a) Sample land surface landscape; (b) The sensors were installed in the soil at different depths.

Soil water storage, defined as the actual water content in a soil sample of a given thickness under natural conditions, and expressed in mm precipitation, is calculated as follows:

$$
\mathrm{W}=\mathrm{F} \times \mathrm{H} \times \mathrm{Wm} \times 10
$$

where $\mathrm{W}$ is the soil water storage $(\mathrm{mm}), \mathrm{F}$ is the bulk density of the soil $(\mathrm{g} / \mathrm{cm} 3), \mathrm{H}$ is the thickness of the soil $(\mathrm{cm})$ and Wm is the soil- moisture content (wt.\%).

The data of soil moisture content from the automatic soil moisture monitoring system are volumetric water content $(\mathrm{Wv})$. So it should be changed to mass water content $(\mathrm{Wm})$ :

$$
\mathrm{Wm}=\mathrm{Wv} \times \rho \mathrm{b}
$$

where $\mathrm{Wm}$ is the mass water content (wt.\%), $\mathrm{Wv}$ is the volumetric water content (vol\%) and $\varrho \mathrm{b}$ is the soil bulk density $\left(\mathrm{g} / \mathrm{m}^{3}\right)$.

\subsection{Statistical Analysis}

Correlation analysis, regression analysis and variance analysis are common statistical methods in grassland water storage research. These analytical methods aren't very useful, however, as they have some defects in analyzing the relationship between complex environmental factors and soil water storage. There are so many environmental factors that often have cooperative changes, and a single factor can explain very small variations in water storage. Regression analysis is often used to analyze the linear relationship between a small number of independent variables and dependent variables. While it doesn't apply to multiple environmental factors, there's probably a nonlinear relationship [16]. Stronger collinearities and nonlinearities were observed among meteorological variables than among environmental variables; however, it is inappropriate to examine the individual effects of environmental 
variables on soil water storage based solely on the coefficients of independent variables in a multiple regression analysis. Therefore, the boosted regression trees (BRT) model was adopted to quantitatively evaluate the relative influence of environmental variables on soil water storage [17]. The BRT model analyses were conducted in R (software version 3.03). Finally, Structural Equation Modelling (SEM) was applied to select the appropriate variables. Here, SEM was used to explicitly evaluate both the direct and indirect effects of these environmental elements on soil water storage.

\section{Results}

\subsection{Soil Water Content in Four Grassland Degradation Classes}

NG, LG, MG and SG showed different soil moisture dynamics in each layer. Soil moisture at 0-10 $\mathrm{cm}$ and 10-20 cm fluctuated widely throughout the growing season, but remained relatively steady at $30-40 \mathrm{~cm}$. Grassland degradation had a significant effect on soil moisture content, and the vertical distribution of soil moisture varied among the different degrees of degradation (Figure 2). The soil water content in NG decreased in the following order: $10-20 \mathrm{~cm}(44.6 \pm 4.3 \%)>20-40 \mathrm{~cm}(34.5$ $\pm 2.1 \%)>0-10 \mathrm{~cm}(33.1 \pm 4.4 \%)$, with differences significant at $p<0.05$. The order in LG was $20-40 \mathrm{~cm}$ $(31.2 \pm 1.7 \%)>10-20 \mathrm{~cm}(27.2 \pm 3.6 \%)>0-10 \mathrm{~cm}(21.2 \pm 4.2 \%)$, with differences significant at $p<0.05$. The soil water content in each layer gradually decreased under increasing grassland degradation (Table 2): compared with NG, soil moisture contents at $0-10 \mathrm{~cm}$ depth decreased by $35.9 \%, 10.0 \%$ and $45.6 \%$ in LG, MG and SG, respectively. The effect of degradation on the soil water content at $20-40 \mathrm{~cm}$ depth was not as obvious as that of the surface layer; compared with NG, soil moisture content at $20-40 \mathrm{~cm}$ depth decreased by $9.6 \%, 36.8 \%$ and $22.6 \%$ in LG, MG and SG, respectively. Soil moisture loss at the depths of $0-10 \mathrm{~cm}$ and $10-20 \mathrm{~cm}$ was greater than that in the $20-40 \mathrm{~cm}$ soil layer.

Table 2. Water content in the four plots during the studied period.

\begin{tabular}{cccc}
\hline $\begin{array}{c}\text { Degradation } \\
\text { Classification }\end{array}$ & $\begin{array}{c}\text { Water Content (vol\%) } \\
\mathbf{0 - 1 0} \mathbf{~ c m ~}\end{array}$ & $\begin{array}{c}\text { Water Content (vol\%) } \\
\mathbf{1 0 - 2 0 ~} \mathbf{~ m ~}\end{array}$ & $\begin{array}{c}\text { Water Content (vol\%) } \\
\mathbf{2 0 - 4 0 ~} \mathbf{~ c m}\end{array}$ \\
\hline NG & $33.1 \pm 4.4^{* *}$ & $44.6 \pm 4.3^{* *}$ & $34.5 \pm 2.1^{* *}$ \\
LG & $21.2 \pm 4.2^{* *}$ & $27.2 \pm 3.6^{* *}$ & $31.2 \pm 1.7^{* *}$ \\
MG & $29.7 \pm 4.8^{* *}$ & $26.2 \pm 4.3^{* *}$ & $21.8 \pm 1.0^{* *}$ \\
SG & $18.0 \pm 5.3^{* *}$ & $24.3 \pm 4.9^{* *}$ & $26.7 \pm 1.2^{* *}$ \\
\hline
\end{tabular}

The value of Water Content is the mean of 2017 and 2018. One-way anova was used to compare the same layer of soil between different treatments. ${ }^{* *}$ Means significant different level reach 0.01 . 

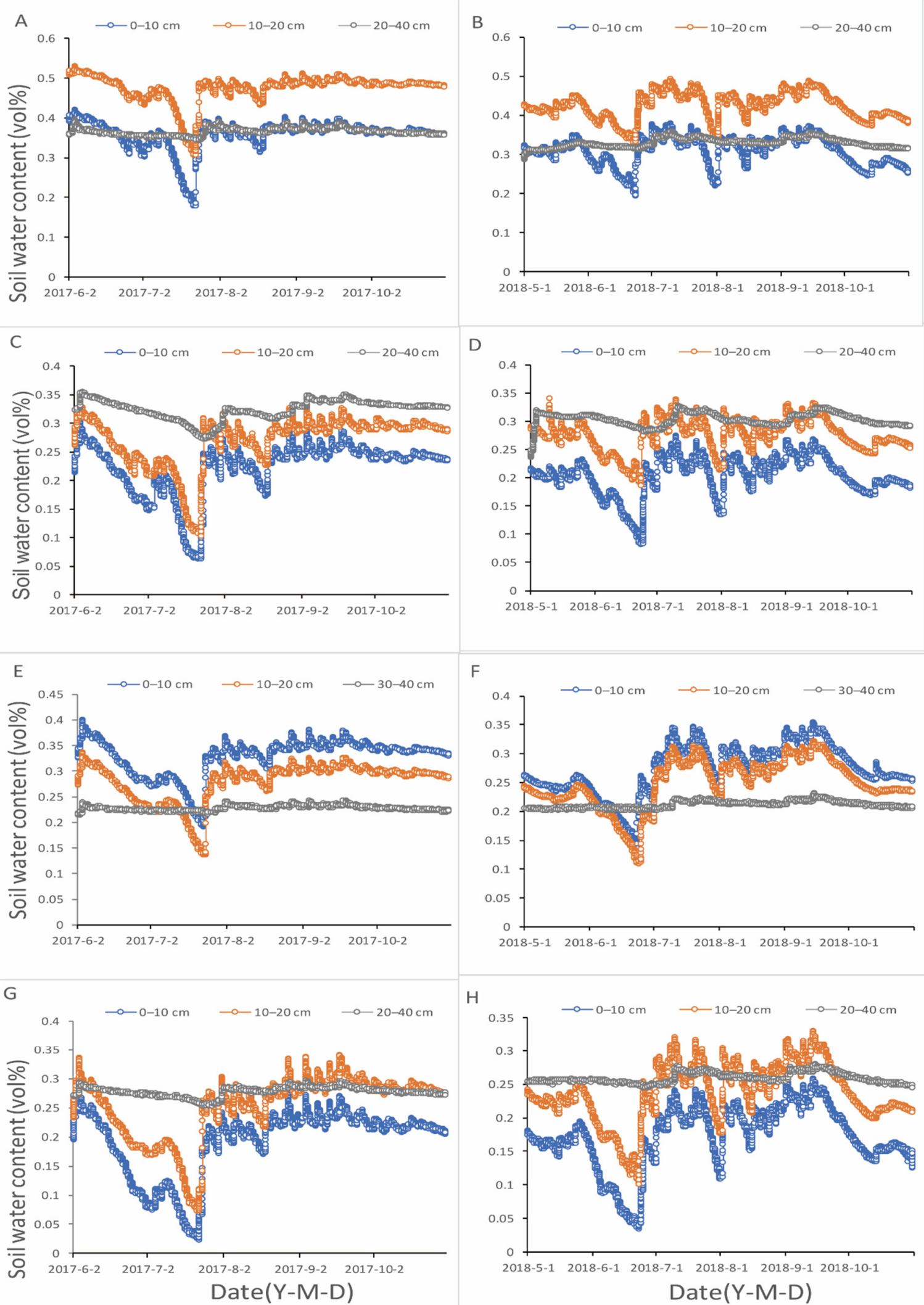

Figure 2. Changes in grassland water content during the growing season. * Water content of NG in 2017 (A) and 2018 (B); water content of LG in 2017 (C) and 2018 (D); water content of MG in 2017 (E) and 2018 (F); water content of SG in 2017 (G) and $2018(\mathbf{H})$. 


\subsection{Soil Water Storage in the Four Plots with Varying Degrees of Degradation}

Because of the melting of seasonally frozen soil, there were obvious seasonal fluctuations in soil water storage at $0-40 \mathrm{~cm}$ soil depth in the alpine grassland. Soil water storage peaked at the beginning of the growing season in May and then gradually decreased (Figure 3). The lowest soil water content appeared in mid-July. Soil water storage increased again in September as some plants withered. Soil water storage decreased gradually but significantly $(p<0.05)$ with increasing degradation severity: soil water storage was reduced by $35.9 \mathrm{~mm}$ in lightly degraded grassland; when compared with NG, the soil water storage in LG, MG and HM decreased by 24.5\%, 32.1\% and 36.7\%, respectively.

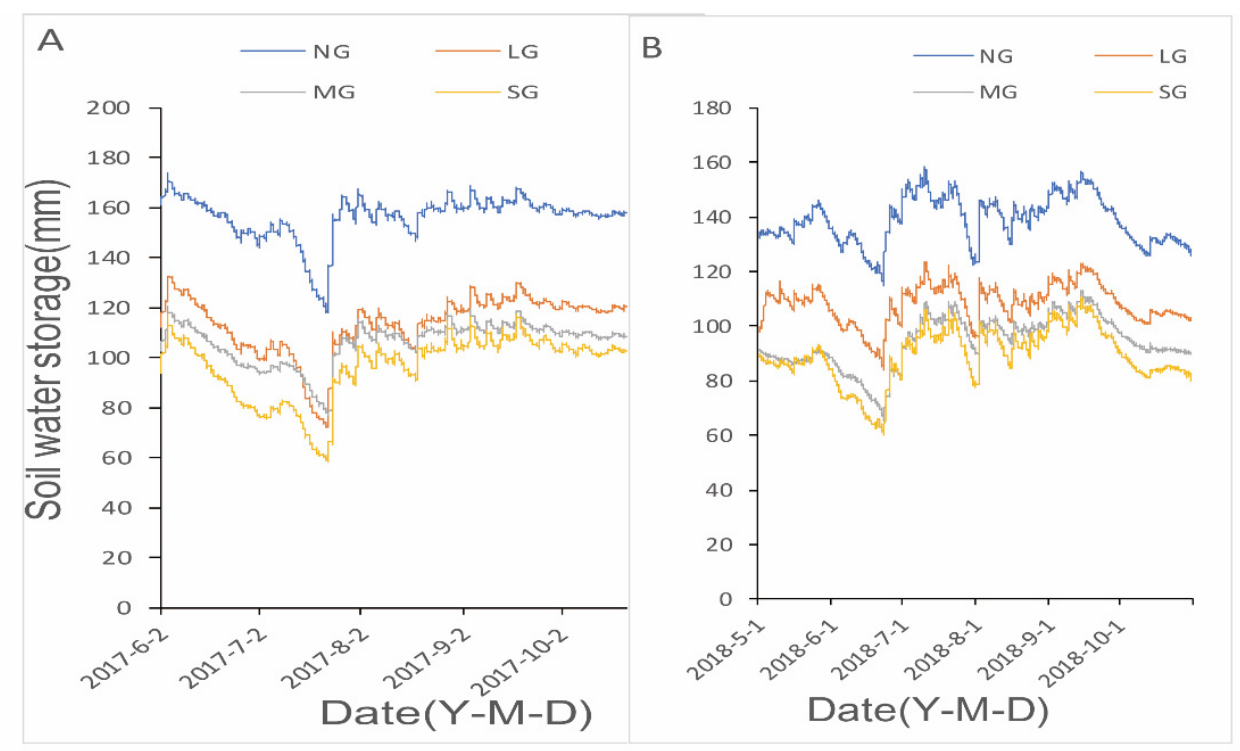

Figure 3. Changes in soil water storage during the growing season in four plots. Soil water storage in 2017 (A) and 2018 (B) at NG, LG, MG and SG.

\subsection{Factors Influencing Water Storage in Alpine Grasslands}

To identify the key factors affecting soil water storage in alpine grasslands, we selected 12 environmental factors (wind speed, air temperature, humidity, atmospheric pressure, precipitation, total radiation, reflected radiation, ultraviolet radiation, net radiation, effective radiation, soil heat flux and groundwater level) as well as four vegetation characteristics (above-ground biomass, vegetation cover, litter and root biomass) and then carried out a correlation analysis. Results showed that six factors (wind speed, air temperature, precipitation, net radiation, soil heat flux and underground water level) had a significant effect on soil water storage $(p<0.05)$. The factors that showed a significant positive correlation with soil water storage were wind speed $(\mathrm{r}=0.118, p<0.01)$, precipitation $(\mathrm{r}=0.115$, $p<0.01)$, net radiation $(\mathrm{r}=0.116, p<0.01)$, soil heat flux $(\mathrm{r}=0.104, p<0.01)$ and litter $(\mathrm{r}=0.069$, $p<0.01)$. The negatively correlated factors were air temperature $(\mathrm{r}=-0.152, p<0.01)$, underground water level $(\mathrm{r}=-0.507, p<0.01)$ and vegetation coverage $(\mathrm{r}=-0.224, p<0.01)$.

Through the correlation analysis, we found eight factors significantly correlated with soil water storage. To further understand how these eight factors jointly affect soil water storage, we ran the SEM model with wind speed, air temperature, precipitation, net radiation, soil heat flux, groundwater level, vegetation cover, grass litter and water storage. The SEM model explains 44.1\%, 72.7\%, 9.3\% and $56.7 \%$ of the variation in vegetation coverage, above-ground biomass, litter and soil water storage, respectively (Figure 4). The model does not adequately explain the variation in litter, so there must be other important factors not considered by the model. Groundwater level, air temperature, soil heat flux, wind speed, precipitation, above-ground biomass and litter had direct and significant effects on soil water storage $(p<0.05)$. Soil heat flux was a very important environmental factor, which significantly 
inhibited the above-ground biomass and coverage of grassland $(p<0.05)$, and had a significant promoting effect on soil water storage $(p<0.05)$. Groundwater level directly affected grassland biomass and soil water storage: as the ground water level increased, biomass and water storage both increased. Air temperatures also significantly promoted vegetation coverage, above-ground biomass and soil water storage $(p<0.05)$.

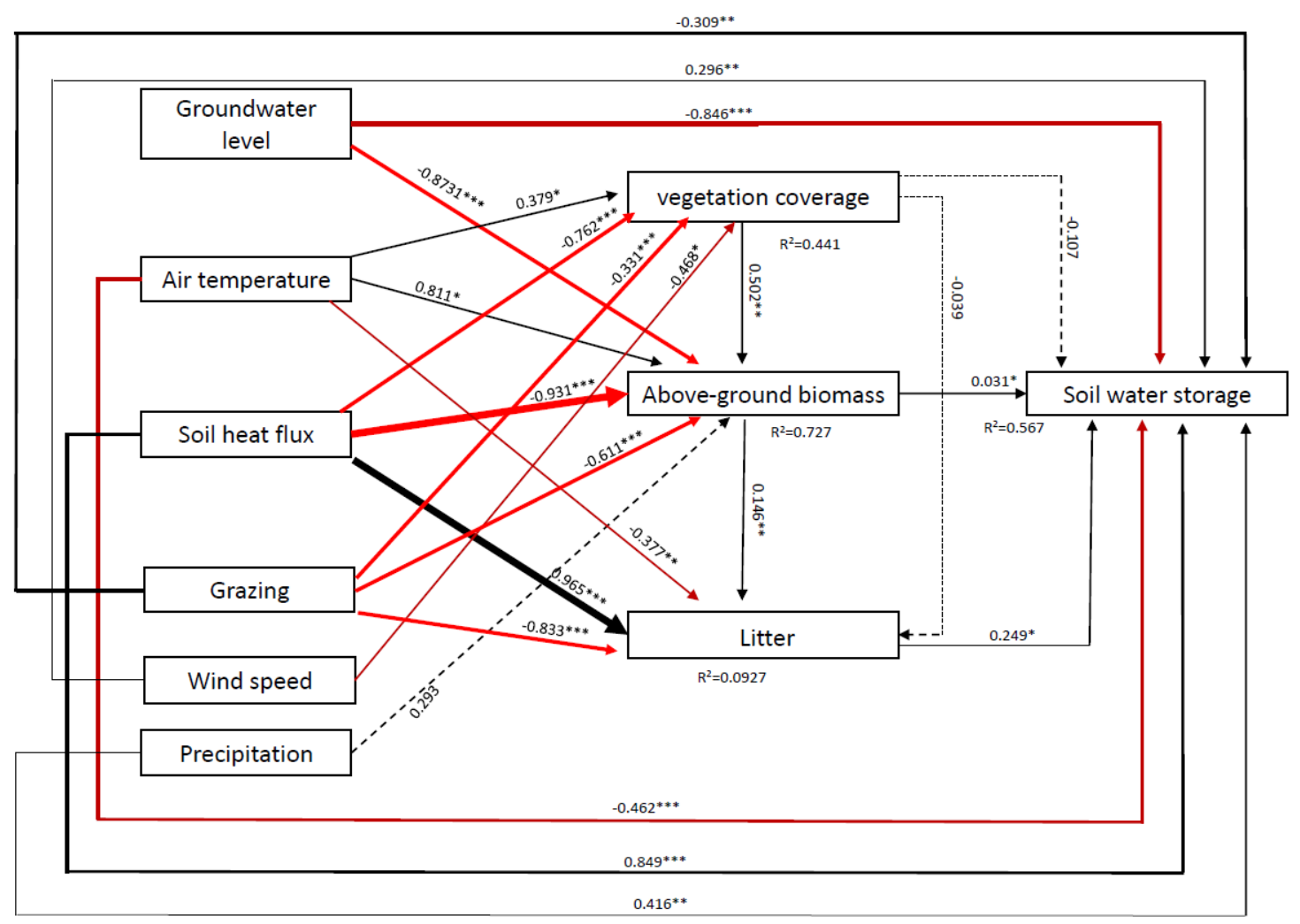

Figure 4. A structural equation model of the effect of environmental factors on soil water storage. The results of the final structural equation modeling reveal the causal relationships among soil water storage, wind speed, air temperature, precipitation, net radiation, soil heat flux and underground water level. Some paths that were not significant at the $p<0.05$ level were deleted from the final model to conserve parameters and to maintain statistical power. Red and black arrows represent significant negative and positive pathways, respectively, and grey dashed arrows indicate nonsignificant pathways. Arrow width indicates the strength of the causal effect. Numbers above arrows indicate path coefficients $\left({ }^{*} p<0.05,{ }^{* *} p<0.01,{ }^{* * *} p<0.001\right) . \mathbf{R}^{2}$ is the proportion of variation explained by all paths.

Dominance analysis can identify the individual contributions of each of the nine environmental factors influencing soil water storage. The key factors that influence water storage are, in order of decreasing contribution: groundwater level, air temperature, soil heat flux, grazing, wind speed, above-ground biomass, precipitation, litter and vegetation coverage. Their percentage contributions to soil water storage are $35.6 \%, 25.3 \%, 8.16 \%, 7.96 \%, 5.16 \%, 5.05 \%, 4.79 \%, 4.51 \%$ and $2.34 \%$ (Figure 5), respectively. This analysis shows that the role of environmental factors in determining soil water storage was greater than that of vegetation factors. Groundwater level and air temperature together explained $66.2 \%$ of the total variation in soil water storage and accordingly were the key factors controlling grassland water storage. Grazing was the most important anthropogenic factor, while vegetation characteristics (above-ground biomass, litter, vegetation coverage) together explained $11.9 \%$ of the total variation, and were therefore also very important factors affecting soil water storage. 


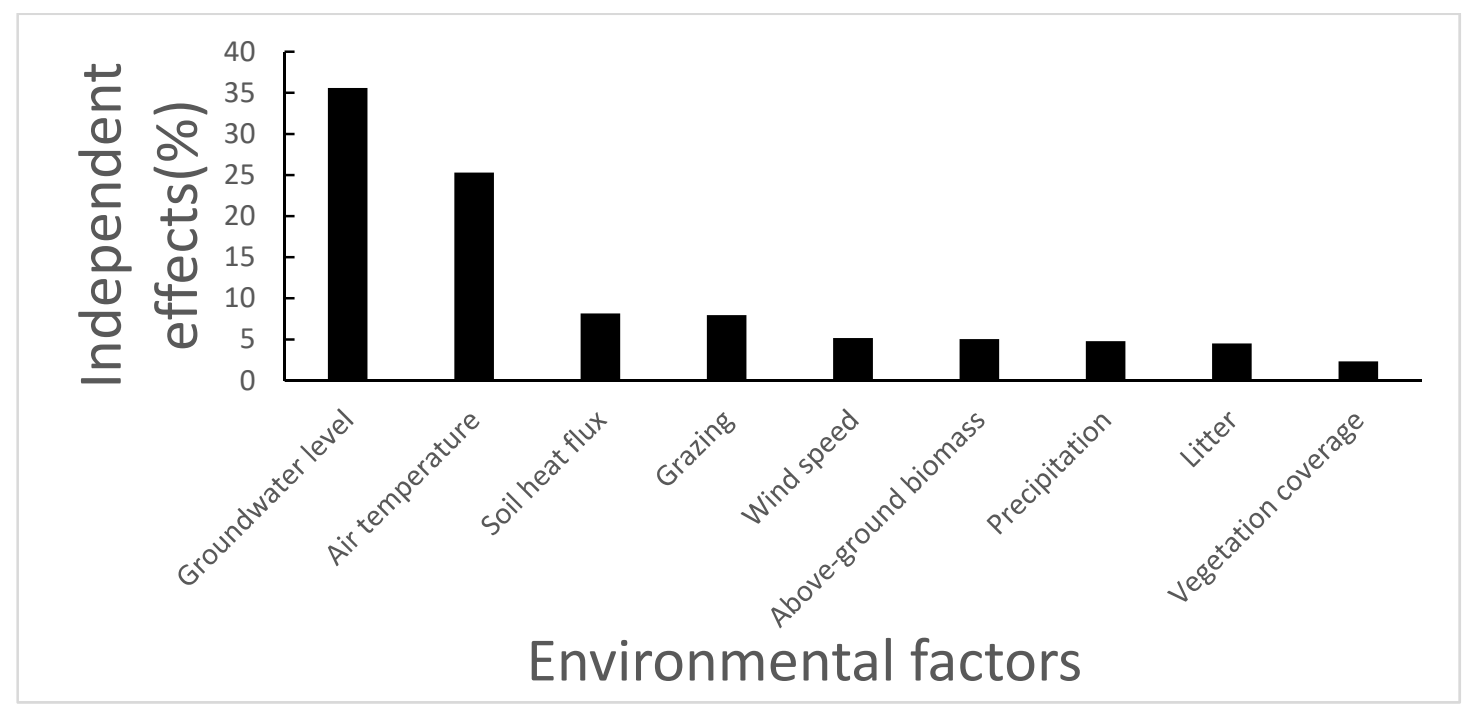

Figure 5. Independent effects of environmental factors on soil water storage.

\section{Discussion}

\subsection{Factors Influencing Grassland Water Storage}

The first peak in soil water storage observed in mid-May could be due to the presence of water from the thawing of seasonally frozen soil [18]. The lowest value of soil water storage occurred in July or August, during the peak growing season, which is when both the transpiration capacity of the vegetation and precipitation reached a maximum. Heavy grazing reduced the protection of vegetation and litter, and also adversely affected the soil environment. The above-ground biomass showed a significant negative correlation with soil water storage, while grass litter explained $24.02 \%$ of the variation in soil water storage. Litter and ground vegetation had similar functions: both could intercept precipitation, condense dew, increase water storage and improve the hydrothermal environment of the grassland. Furthermore, the litter did not consume any water. Therefore, an increase in the quantity of litter improved the soil's water permeability and retention capacity, and indirectly improved the soil's water-conservation function, as supported by the studies of Zvirzdin et al. [19] and Wall and Heiskanen [20], respectively.

Shallow groundwater is an important contributor to grassland moisture: the deeper the water table, the less compensation it provides for grassland moisture losses. In this study, there was a significant negative correlation between the depth to groundwater and soil water storage (i.e., a shallow ground water level is associated with greater water storage). The deepest groundwater level under the alpine grassland was observed in the peak growing season [18], coincident with the minimum in soil water storage. Air temperature was the second most important environmental factor affecting grassland water storage: an increase in temperature significantly reduced the amount of soil water storage. Across the Tibetan plateau in summer, rising temperatures promote evaporation and transpiration [21] and evaporation far outweighs precipitation; therefore, the lowest soil water storage in the alpine grassland occurs in summer. It has been reported that the world has already warmed by $1.0^{\circ} \mathrm{C}$ since preindustrial levels, and is expected to continue warming at a rate of $0.2 \pm 0.1^{\circ} \mathrm{C}$ per year [22]. Against this background of rising temperature, soil water storage in the alpine grassland of the Qinghai-Tibet Plateau will decrease significantly.

\subsection{Grazing Significantly Reduced Soil Water Storage}

Grazing intensity had the greatest influence on surface soil moisture content of the grassland [23], while changes at a depth of $40 \mathrm{~cm}$ were less obvious. In the process of grassland degradation, above-ground biomass reduced, the effect of vegetation on soil evaporation weakened, and the 
rainwater infiltration rate decreased. All these were not conducive to soil moisture supplement [24]. It has been reported that the water capacity of litter in heavily grazed grasslands is only $95 \%$ of that in native grasslands, and litter also proved to be the key control factor of soil water storage in this study [25]. The soil bulk density increased gradually under the trample action of grazing cattle and sheep [26], which reduced the pores in the soil and thereby was not conducive to soil moisture adsorption.

Under light degradation, the grassland soil water storage was significantly reduced (by $24.5 \%$ ); under light grazing, the grassland soil moisture at $0-10$ and $10-20 \mathrm{~cm}$ was reduced by 35.9 and $39 \%$, respectively; under heavy grazing, the respective decreases reached $45.6 \%$ and $45.5 \%$. Grazing altered the vertical distribution of water in the soil: the soil water content at $10-20 \mathrm{~cm}$ in native grassland was significantly higher than that at $0-10 \mathrm{~cm}$ and at $20-40 \mathrm{~cm}$, which is beneficial for plant growth and reduced evaporation; however, with increasing grazing intensity, soil moisture at $10-20 \mathrm{~cm}$ was greatly reduced, resulting in the $20-40 \mathrm{~cm}$ soil layer having the highest water content. This vertical water distribution in the soil facilitated the growth of deep-rooted plants (grasses and weeds), but since the grasses were eaten by cattle and sheep, the weeds were able to grow in abundance, which exacerbated the grassland degradation [27]. Further grassland degradation will make the soil water storage lose protection and will cause further loss.

\section{Conclusions}

Soil water storage is significantly reduced even in lightly degraded grassland. When compared with NG, the soil water storage in LG, MG and SG decreased by $24.5 \%, 32.1 \%$ and $36.7 \%$, respectively. A shallow groundwater table, air temperature and grass litter were the key controlling factors of soil water storage in grassland.

Author Contributions: All authors have read and agree to the published version of the manuscript. Conceptualization, X.G. and Y.D.; methodology, L.D.; software, D.Q.; validation, Q.L.; formal analysis, X.G.; investigation, X.G.; resources, G.C.; data curation, D.Q.; writing—original draft preparation, X.G.; writing一review and editing, Y.D. and H.Z.; visualization, X.G.; supervision, Y.D.; project administration, X.G.; funding acquisition, X.G.

Funding: This work was supported by the National Natural Science Foundation of China (41730752, 31700395, 31470530), the Natural Science Foundation of Qinghai (2020-ZJ-916), and the Qinghai innovation platform construction project (2017-ZJ-Y20). Two anonymous reviewers are thanked for detailed evaluations of and constructive suggestions for this manuscript. The funders had no role in study design, data collection and analysis, decision to publish or the preparation of the manuscript.

Conflicts of Interest: The authors declare no conflict of interest.

\section{References}

1. Wang, G.; Liu, G.; Li, C. Effects of changes in alpine grassland vegetation cover on hillslope hydrological processes in a permafrost watershed. J. Hydrol. 2012, 444, 22-33. [CrossRef]

2. Dong, Q.-M.; Zhao, X.-Q.; Wu, G.-L.; Shi, J.-J.; Ren, G.-H. A review of formation mechanism and restoration measures of "black-soil-type" degraded grassland in the Qinghai-Tibetan Plateau. Environ. Earth Sci. 2013, 70, 2359-2370. [CrossRef]

3. Ren, G.; Shang, Z.; Long, R.; Hou, Y.; Deng, B. The relationship of vegetation and soil differentiation during the formation of black-soil-type degraded meadows in the headwater of the Qinghai-Tibetan Plateau, China. Environ. Earth Sci. 2013, 69, 235-245. [CrossRef]

4. Gomez-Plaza, A.; Martinez-Mena, M.; Albaladejo, J.; Castillo, V.M. Factors regulating spatial distribution of soil water content in small semiarid catchments. J. Hydrol. 2001, 253, 211-226. [CrossRef]

5. Zhao, Z.Z.; Zhao, K.; Xu, J.B.; Xiao, Z.F.; Cui, J.F.; Hong, Z. Spatial-temporal Changes of Surface Albedo and Its relationship with Climate Factors in the Source of Three rivers region. Arid Zone Res. 2014, 31, 1031-1038. 
6. Walker, D.A.; Jia, G.J.; Epstein, H.E.; Raynolds, M.K.; Chapin, F.S.; Copass, C.; Hinzman, L.D.; Knudson, J.A.; Maier, H.A.; Michaelson, G.J.; et al. Vegetation-soil-thaw-depth relationships along a Low-Arctic bioclimate gradient, Alaska: Synthesis of information from the ATLAS studies. Permafr. Periglac. Process. 2003, 14, 103-123. [CrossRef]

7. Eshtawi, T.; Evers, M.; Tischbein, B.; Diekkrueger, B. Integrated hydrologic modeling as a key for sustainable urban water resources planning. Water Res. 2016, 101, 411-428. [CrossRef]

8. Dec, D.; Doerner, J.; Balocchi, O.; Lopez, I. Temporal dynamics of hydraulic and mechanical properties of an Andosol under grazing. Soil. Till. Res. 2012, 125, 44-51. [CrossRef]

9. Pan, T.; Hou, S.; Wu, S.; Liu, Y.; Liu, Y.; Zou, X.; Herzberger, A.; Liu, J. Variation of soil hydraulic properties with alpine grassland degradation in the eastern Tibetan Plateau. Hydrol. Earth Syst. Sci. 2017, 21, 2249-2261. [CrossRef]

10. Li, J.; Zhang, F.; Lin, L.; Li, H.; Du, Y.; Li, Y.; Cao, G. Response of the plant community and soil water status to alpine Kobresia meadow degradation gradients on the Qinghai-Tibetan Plateau, China. Ecol. Res. 2015, 30, 589-596. [CrossRef]

11. Su, L.; Yang, Y.; Li, X.; Wang, D.; Liu, Y.; Liu, Y.; Yang, Z.; Li, M. Increasing plant diversity and forb ratio during the revegetation processes of trampled areas and trails enhances soil infiltration. Land Degrad. Dev. 2018, 29, 4025-4034. [CrossRef]

12. Jiang, C.; Li, D.; Wang, D.; Zhang, L. Quantification and assessment of changes in ecosystem service in the Three-River Headwaters Region, China as a result of climate variability and land cover change. Ecol. Indic. 2016, 66, 199-211. [CrossRef]

13. FAO. FAO World Reference Base for Soil Resources 2014: International Soil Classification System for Naming Soils and Creating Legends for Soil Maps; FAO: Roma, Italy, 2015.

14. Whitford, W.G.; Soyza, A.G.D.; Zee, J.W.V.; Herrick, J.E.; Havstad, K.M. Vegetation, Soil, and Animal Indicators of Rangeland Health. Environ. Monit. Assess. 1998, 51, 179-200. [CrossRef]

15. Du, Y.; Zhou, G.; Guo, X.; Cao, G. Spatial distribution of grassland soil organic carbon and potential carbon storage on the Qinghai Plateau. Grassl. Sci. 2019, 65, 141-146. [CrossRef]

16. Martínez-Rincón, R.O.; Ortega-García, S.; VacaRodríguez, J.G. Comparative performance of generalized additive models and boosted regression trees for statistical modeling of incidental catch of wahoo (Acanthocybium solandri) in the Mexican tuna purse-seine fishery. Ecol. Model. 2012, 233, 20-25. [CrossRef]

17. Elith, J.; Leathwick, J.R.; Hastie, T. A working guide to boosted regression trees. J. Anim. Ecol. 2008, 77, 802-813. [CrossRef]

18. Dai, L.; Guo, X.; Du, Y.; Zhang, F.; Ke, X.; Cao, Y.; Li, Y.; Li, Q.; Lin, L.; Cao, G. The Response of Shallow Groundwater Levels to Soil Freeze-Thaw Process on the Qinghai-Tibet Plateau. Groundwater 2019, 57, 602-611. [CrossRef]

19. Zvirzdin, D.L.; Roundy, B.A.; Barney, N.S.; Petersen, S.L.; Anderson, V.J.; Madsen, M.D. Postfire soil water repellency in pinon-juniper woodlands: Extent, severity, and thickness relative to ecological site characteristics and climate. Ecol. Evol. 2017, 7, 4630-4639. [CrossRef]

20. Wall, A.; Heiskanen, J. Water-retention characteristics and related physical properties of soil on afforested agricultural land in Finland. Forest Ecol. Manag. 2003, 186, 21-32. [CrossRef]

21. Taylor, R.G.; Scanlon, B.; Döll, P.; Rodell, M.; Treidel, H. Ground water and climate change. Nat. Clim. Change 2013, 3, 322-329. [CrossRef]

22. Bongaarts, J. Intergovernmental Panel on Climate Change Special Report on Global Warming of $1.5^{\circ} \mathrm{C}$ Switzerland: IPCC, 2018. Popul. Devel. Rev. 2019, 45, 251-252. [CrossRef]

23. Sun, G.; Li, Y.; Liu, X.; Cui, N.; Gao, Y.; Yang, Q. Effect of Moistube Fertigation on Infiltration and Distribution of Water-Fertilizer in Mixing Waste Biomass Soil. Sustainability 2019, 11, 6757. [CrossRef]

24. Lin, L.; Li, Y.K.; Xu, X.L. Predicting parameters of degradation succession processes of Tibetan Kobresia grasslands. Solid Earth 2015, 6, 1237-1246. [CrossRef]

25. Colman, C.B.; Oliveira, P.T.S.; Almagro, A.; Soares-Filho, B.S.; Rodrigues, D.B.B. Effects of Climate and Land-Cover Changes on Soil Erosion in Brazilian Pantanal. Sustainability 2019, 11, 7053. [CrossRef] 
26. Dai, L.; Guo, X.; Zhang, F.; Du, Y.; Ke, X.; Li, Y.; Cao, G. Seasonal dynamics and controls of deep soil water infiltration in the seasonally-frozen region of the Qinghai-Tibet plateau. J. Hydrol. 2019, 571, 740-748. [CrossRef]

27. Leemhuis, C.; Thonfeld, F.; Näschen, K.; Steinbach, S.; Muro, J.; Strauch, A.; López, A.; Daconto, G.; Games, I.; Diekkrüger, B. Sustainability in the Food-Water-Ecosystem Nexus: The Role of Land Use and Land Cover Change for Water Resources and Ecosystems in the Kilombero Wetland, Tanzania. Sustainability 2017, 9 , 1513. [CrossRef]

(C) 2020 by the authors. Licensee MDPI, Basel, Switzerland. This article is an open access article distributed under the terms and conditions of the Creative Commons Attribution (CC BY) license (http://creativecommons.org/licenses/by/4.0/). 